\title{
Net flux of nutrients across splanchnic tissues of lactating dairy cows as influenced by dietary supplements of biotin and vitamin $B_{12}{ }^{1}$
}

\author{
C. L. Girard*2 and A. Desrocherst \\ *Agriculture et Agroalimentaire Canada, Centre de recherche et développement sur le bovin laitier et le porc, Sherbrooke, \\ Québec, J1M 1Z3, Canada \\ †Faculté de Médecine Vétérinaire, Université de Montréal, St-Hyacinthe, Québec, J2S 7C6, Canada
}

\section{ABSTRACT}

Biotin and vitamin $\mathrm{B}_{12}$ are coenzymes in reactions that are essential to propionate metabolism in dairy cows. The objective of the present studies was to determine whether an increased dietary supply of these vitamins would change the net flux of nutrients through the rumen, the portal-drained viscera (PDV), the total splanchnic tissues (TSP), and the liver. Four lactating cows equipped with ultrasonic flow probes around the right ruminal artery and the portal vein and catheters in the right ruminal vein, the portal vein, one hepatic vein, and one mesenteric artery were fed 12 times per day a mixed ration at $95 \%$ of ad libitum dry matter intake. Daily supplements of $500 \mathrm{mg}$ of vitamin $\mathrm{B}_{12}+$ $20 \mathrm{mg}$ of biotin or no vitamin supplement (study 1) or $500 \mathrm{mg}$ of vitamin $\mathrm{B}_{12}$ alone or with $20 \mathrm{mg}$ of biotin (study 2) were fed according to a crossover design with two 4 -wk periods in each study. On the last day of each period, blood flow was recorded and blood samples were collected every 30 min for $4 \mathrm{~h}$. In study 1, biotin and vitamin $\mathrm{B}_{12}$ given together increased milk production and milk protein yields compared with the control diet. The supplement increased appearance of the 2 vitamins across the PDV and TSP. It also reduced the net portal appearance of ammonia and total volatile fatty acids across the PDV. In study 2, compared with the 2 vitamins together, vitamin $\mathrm{B}_{12}$ alone increased glucose flux across PDV and TSP as well as its arterial concentration and PDV flux of ammonia. With the diet used in the present experiment, the major effects of the vitamin supplements seem to be mediated through changes in ruminal fermentation and gastrointestinal tract metabolism rather than by effects on hepatic metabolism.

Key words: dairy cow, portal-drained viscera, biotin, vitamin $\mathrm{B}_{12}$

Received August 24, 2009.

Accepted December 1, 2009.

${ }^{1}$ Contribution no. 1030.

${ }^{2}$ Corresponding author: Christiane.Girard@agr.gc.ca

\section{INTRODUCTION}

The nature of the ruminant digestive system imposes a huge dependence on gluconeogenesis because very little glucose is being absorbed (Reynolds, 2006). In ruminants, the rate of gluconeogenesis increases with feed intake (Hocquette and Bauchart, 1999), and one of the major substrates for gluconeogenesis is propionate (Reynolds, 2006). Seal et al. (1992) observed that, in growing steers, $83 \%$ of the absorbed propionate was used for glucose synthesis representing approximately $50 \%$ of the whole-body glucose flux.

Metabolic utilization of propionate after its absorption from the gastrointestinal tract is dependent on the transformation of propionate into succinyl-coenzyme A (CoA), requiring the successive actions of biotin- and vitamin $\mathrm{B}_{12}$-dependent enzymes. Propionate is first transformed into propionyl-CoA, which is carboxylated to methylmalonyl-CoA by a biotin-dependent enzyme, propionyl-CoA carboxylase. Methylmalonyl-CoA is then isomerized in succinyl-CoA under the action of the vitamin $\mathrm{B}_{12}$-dependent enzyme, methylmalonyl-CoA mutase. Succinyl-CoA finally enters into the Krebs cycle, from where it can be directed toward gluconeogenesis (Le Grusse and Watier, 1993; McDowell, 2000). Moreover, biotin is also a coenzyme for the pyruvate carboxylase, which catalyzes the carboxylation of pyruvate in oxaloacetate for glucose synthesis (McMahon, 2002).

The effects of dietary supplements of biotin or vitamin $\mathrm{B}_{12}$ on dairy cow metabolism are, however, not clearly defined. On one hand, dietary supplementation with biotin is frequently reported to increase milk production (Girard and Matte, 2006; Ferreira et al., 2007; Enjalbert et al., 2008), but its effect on plasma glucose concentrations is variable (Girard and Matte, 2006; Reynolds et al., 2007). On the other hand, compared with a control diet, a combined supplement of vitamin $\mathrm{B}_{12}$ and folic acid tended to increase whole-body glucose flux and milk lactose yield with a similar quantitative magnitude (Preynat et al., 2009). Moreover, Graulet et al. (2007) observed that, in cows fed supplementary folic acid, a supplement of vitamin $\mathrm{B}_{12}$ increased 
plasma concentrations of glucose while decreasing plasma concentrations of biotin. Nevertheless, dietary supplements of B-vitamins could also possibly affect ruminal microflora altering ruminal fermentation and nutrient availability for the cow, especially at the doses used in the production studies reported above. In vitro, omission of biotin from the culture media decreased VFA production by ruminal bacteria (Milligan et al., 1967). Scott and Dehority (1965) demonstrated that some cellulolytic bacteria had absolute requirements for biotin and vitamin $\mathrm{B}_{12}$ whereas other species require only biotin. In vivo studies, however, failed to detect any effect of dietary supplements of biotin on molar concentrations of VFA in ruminal fluid (Zimmerly and Weiss, 2001; Majee et al., 2003; Ferreira et al., 2007).

The present studies aimed to determine whether an increased dietary supply of biotin and vitamin $\mathrm{B}_{12}, 2$ vitamins essential to propionate utilization and gluconeogenesis could change the net release or uptake of nutrients by the rumen wall, portal-drained viscera (PDV), liver, and total splanchnic tissues (TSP).

\section{MATERIALS AND METHODS}

Care of cows followed the recommended code of practice of Agriculture Canada (1990) and the guidelines of the Canadian Council on Animal Care (1993). Surgical procedures were reviewed and accepted by the Institutional Committee on Animal Care of the Dairy and Swine Research and Development Centre (Sherbrooke, Québec, Canada).

\section{Cows and Treatments}

Eight weeks after calving, 4 lactating cows were surgically equipped with ultrasonic flow probes around the right ruminal artery (8-mm flow probes, R-series, Transonic Systems, Ithaca, NY) and the portal vein (32-mm flow probes, A-series, Transonic Systems) using adaptations of the surgical methods developed for sheep by Rémond et al. (1993; 1998). Indwelling catheters (Tygon tubing, $0.05 \mathrm{~mm}$ i.d., $0.09 \mathrm{~mm}$ o.d., Norton Performance Plastics, Akron, $\mathrm{OH}$ ) treated with tridodecylmethylammonium chloride heparin complex [2\% (wt/wt), Polysciences Inc., Warrington, PA] were placed in the right ruminal vein, the portal vein, one hepatic vein, and one mesenteric artery. Briefly, a flow probe was placed around the ruminal artery a few centimeters beyond the point of entry of the vessel on the right ruminal wall, and the catheter was placed in the right ruminal vein with its tip equal to the flow probe. The other flow probe was placed around the hepatic portal vein after the junction with the gastrosplenic vein and before the entry of the portal vein in the liver. A small incision was made in the liver; a first catheter was then inserted in the vein and directed toward the portal vein, its tip placed just at the entry of the portal vein in the liver. A second catheter was then inserted in one hepatic vein and pushed until its tip rested outside the liver. At the time of the surgery, placement of these catheters was verified by echography and blood gas differences from blood drawn from the 2 catheters. The last catheter was placed in one mesentery artery with its entry at the ileal level. At postmortem examination, after exsanguination, the tip of the catheters in the right ruminal vein rested from 0 to $6 \mathrm{~cm}$ beyond the flow probe placed around the artery. The tip of the catheters placed in the portal vein was close to the liver, more than $6 \mathrm{~cm}$ before the flow probe. The tip of the catheters in a hepatic vein was outside the liver, more than $5 \mathrm{~cm}$ before the junction with the vena cava.

Cows were kept in a tie-stall barn under $16 \mathrm{~h}$ of light per day (0530-2130 h) and were milked twice daily at a 12-h interval. Cows had free access to water. One kilogram of hay was served at $0700 \mathrm{~h}$ and the mixed ration (Table 1 ) was served in 12 equal meals per day, every $2 \mathrm{~h}$. Vitamin supplements were incorporated in equal amounts into each meal. Before the beginning of each study, voluntary feed intake was measured for each cow for a 1-wk period. Thereafter, during the experiment, the ration was served at $95 \%$ of the voluntary feed intake. Refusals, if present, were weighed daily at $1000 \mathrm{~h}$.

This project was divided into 2 studies according to a crossover design with 2 periods of 4 wk each. There was a wash-out period of $7 \mathrm{~d}$ between the 2 studies. In study 1 , the treatments were 1) no vitamin supplement $\left(\mathbf{B}_{8}-\mathbf{B}_{12}-\right)$ or 2) $20 \mathrm{mg}$ of biotin $+500 \mathrm{mg}$ of vitamin $\mathrm{B}_{12}$ (cyanocobalamin) per day $\left(\mathbf{B}_{8}+\mathbf{B}_{12}+\right)$. In study 2 , the treatments were daily supplements of $500 \mathrm{mg}$ of vitamin $\left.\mathbf{B}_{12} 1\right)$ alone $\left(\mathbf{B}_{8}-\mathbf{B}_{12}+\right)$ or 2$)$ combined with $20 \mathrm{mg}$ of biotin $\left(\mathbf{B}_{\mathbf{8}}+\mathbf{B}_{12}+\right)$. Doses were chosen according to Zimmerly and Weiss (2001) and Graulet et al. (2007). Cows were at $118 \pm 5.6$ and $181 \pm 5.6$ DIM at the beginning of studies 1 and 2, respectively.

\section{Feed Analysis}

At the beginning of the experiment, hay samples were collected in different hay bales harvested in 1 field and pooled. Silage samples were collected twice a week. A subsample was immediately analyzed by near-infrared reflectance spectrometry. Another subsample was frozen at $-20^{\circ} \mathrm{C}$ and pooled by period for further analyses of DM, CP, soluble protein (AOAC, 2000), ADF, NDF, and acid-detergent lignin (Ankom200 fiber analyzer, Ankom Technology Corp., Fairport, NY). 


\section{Milk Sampling Procedure and Analyses}

Milk production was recorded at each milking during the entire experiment. Milk samples were collected at 2 consecutive milkings at the end of each experimental period. Milk composition (DM, fat, CP, and ash) was determined as described by Girard et al. (2005).

\section{Blood Sampling Procedure and Analyses}

On the last day of each 4 wk-period, blood samples $(\mathrm{n}=8)$ were taken simultaneously from the 4 catheters every 30 min during 4 consecutive hours starting at the $0800 \mathrm{~h}$ meal. Heparinized tubes were used for urea, ammonia, BHBA, glucose, biotin, and VFA. Blood samples were immediately placed on ice and kept chilled until processed. For serum or plasma, blood was centrifuged within $1 \mathrm{~h}$ after sampling for $12 \mathrm{~min}$ at $1,854 \times g$ and $4^{\circ} \mathrm{C}$. Serum for vitamin $\mathrm{B}_{12}$, plasma for biotin and glucose, and whole blood for VFA determinations were kept frozen at $-20^{\circ} \mathrm{C}$ until assayed. For lactate and BHBA determinations, blood was immediately deproteinized and $0.9 \mathrm{~mL}$ of distilled water and $100 \mu \mathrm{L}$ of perchloric acid $6 N$ were added to $1 \mathrm{~mL}$ of blood. The tubes were mixed thoroughly and left on ice for at least $2 \mathrm{~h}$. The tubes were then centrifuged for $30 \mathrm{~min}$ at $31,000 \times g$. Supernatant was collected and immediately frozen at $-20^{\circ} \mathrm{C}$ until assayed. Blood for ammonia determination was deproteinized as described previously. Then, $1 \mathrm{~mL}$ of supernatant was collected and $\mathrm{pH}$ was adjusted to 7.0 with $\mathrm{KHCO}_{3} 2.0 M$. It was then thoroughly mixed, let to stand on ice for $15 \mathrm{~min}$, and then centrifuged for 12 min at $1,854 \times g$ and $4^{\circ} \mathrm{C}$. Supernatant was collected for immediate analysis.

Vitamin $\mathrm{B}_{12}$ in plasma was determined in duplicate by radioassay with a commercial kit (Quantaphase $\mathrm{B}_{12}$, Bio-Rad Laboratories Ltd., Mississauga, Ontario, Canada) as described by Girard and Matte (1988). Plasma biotin was determined using an ELISA test as described by Santschi et al. (2005a). Plasma glucose, blood BHBA, and lactate were determined using commercial kits (Roche Diagnostics Glucose GmbH, Mannheim, Germany; \#310-uv, Sigma Diagnostics, Oakville, Ontario, Canada; and \#826-A Sigma Diagnostics, respectively). Blood VFA were determined according to Reynolds et al. (1986). Urea-N and ammonia concentrations were measured in fresh blood on the day of sampling with an automatic analyzer (Technicon Autoanalyzer II, Technicon Instruments Corp., Tarrytown, NY) as described by Huntington (1984) and an enzymatic reaction (glutamate dehydrogenase) as described by Bergmeyer and Beutler (1985). Blood hemoglobin was determined colorimetrically using cyanmethemoglobin as the standard (Manet, 1969). Packed cell volume was
Table 1. Ingredients and nutrient composition of the mixed ration fed to dairy cows ${ }^{1}$

\begin{tabular}{lc}
\hline Item & Value \\
\hline Ingredient, \% DM basis $^{2}$ & \\
Corn silage $^{2}$ & 20.4 \\
Hay silage $^{3}$ & 30.6 \\
Corn & 33.7 \\
Soybean meal 49\% & 8.6 \\
Micronized soybean & 0.8 \\
Distillers grain (wheat) & 0.8 \\
Distillers grain (corn) & 0.6 \\
Corn gluten meal & 1.0 \\
Canola meal & 0.8 \\
Calcium carbonate & 0.5 \\
Mineral and vitamin premix ${ }^{4}$ & 2.2 \\
Nutrient composition & 18.1 \\
CP, \% & 12.0 \\
RDP, ${ }^{5} \%$ & 6.1 \\
RUP, ${ }^{5} \%$ & 19.7 \\
ADF, \% & 28.9 \\
NDF, \% & 1.55 \\
NE & , ${ }^{5}$ Mcal/kg of DM \\
MP, ${ }^{5}$ g/kg of DM & 108 \\
\hline
\end{tabular}

${ }^{1}$ The cows also received $1 \mathrm{~kg}$ of long hay per day. Composition: $14.1 \%$ CP, $6.1 \%$ soluble protein, $33.0 \%$ ADF, $53.1 \%$ NDF, and $3.2 \%$ lignin (composite sample).

${ }^{2}$ Composition: $10.6 \pm 0.4 \% \mathrm{CP}, 5.0 \pm 0.3 \%$ soluble protein, $25.9 \pm$ $1.4 \% \mathrm{ADF}, 44.6 \pm 2.1 \% \mathrm{NDF}$, and $2.9 \pm 0.1 \%$ lignin $(\mathrm{n}=4)$.

${ }^{3}$ Composition: $19.7 \pm 0.2 \% \mathrm{CP}, 8.3 \pm 0.4 \%$ soluble protein, $31.5 \pm$ $0.6 \% \mathrm{ADF}, 41.5 \pm 0.7 \% \mathrm{NDF}$, and $5.4 \pm 0.3 \%$ lignin $(\mathrm{n}=4)$.

${ }^{4}$ Contained per kg: $67.8 \mathrm{~g}$ of $\mathrm{Ca}, 66.4 \mathrm{~g}$ of $\mathrm{P}, 39 \mathrm{~g}$ of $\mathrm{Mg}, 150.8 \mathrm{~g}$ of $\mathrm{Na}, 107.8 \mathrm{~g}$ of $\mathrm{Cl}, 6.8 \mathrm{~g}$ of K, $10 \mathrm{~g}$ of S, $2,888 \mathrm{mg}$ of $\mathrm{Fe}, 2,002 \mathrm{mg}$ of $\mathrm{Mn}, 1,896 \mathrm{mg}$ of $\mathrm{Zn}, 462.6 \mathrm{mg}$ of $\mathrm{Cu}, 57.6 \mathrm{mg}$ of I, $34.2 \mathrm{mg}$ of Co, 24 $\mathrm{mg}$ of Se, 398,800 IU of vitamin A, 70,458 IU of vitamin D, and 2,294 IU of vitamin E.

${ }^{5}$ Calculated according to the model of NRC (2001).

determined on fresh samples by microcentrifugation of capillary tubes.

Blood flow in the ruminal artery and the portal vein was recorded continuously from $15 \mathrm{~min}$ before the first sampling time to $15 \mathrm{~min}$ after the last sample was taken. Hepatic blood flow was calculated as 1.23 times the blood flow recorded in the portal vein; this value was obtained from a compilation of data obtained on lactating dairy cows (Hélène Lapierre, Agriculture and Agri-Food Canada, Sherbrooke, Québec, Canada, personal communication).

\section{Calculations and Statistical Analysis}

The net flux of nutrients across the rumen, PDV, and TSP tissues was calculated as described by Girard et al. (2001) except that for each sampling time, the mean blood flow recorded by the flow probe from $15 \mathrm{~min}$ before to 15 after blood sample was used for calculations. Net flux of nutrients across the liver was calculated as the differences between TSP and PDV fluxes. Statistical analyses for arterial concentrations and net flux of nutrients across the rumen, PDV, liver, and TSP 
Table 2. Effects of dietary supplements of vitamin $B_{12}(500 \mathrm{mg})$ and biotin $(20 \mathrm{mg})$ on milk production and composition $(\mathrm{n}=4 \text {; study } 1)^{1}$

\begin{tabular}{lrrrc}
\hline Item & $\mathrm{B}_{8}-\mathrm{B}_{12}-$ & $\mathrm{B}_{8}+\mathrm{B}_{12}+$ & $\mathrm{SEM}$ & $P$-value \\
\hline Milk production, kg/d & 30.4 & 31.6 & 2.8 & 0.04 \\
DMI, kg/d & 23.1 & 23.1 & 0.5 & 0.99 \\
Milk composition, g/kg & & & & \\
TS & 133.3 & 131.1 & 5.5 & 0.26 \\
Fat & 43.6 & 41.2 & 2.8 & 0.20 \\
CP & 34.8 & 34.6 & 2.2 & 0.61 \\
Ash & 7.3 & 7.4 & 0.1 & 0.30 \\
Lactose & 47.7 & 48.0 & 0.7 & 0.75 \\
Milk component yield, g/d & & & & \\
TS & 4,010 & 4,091 & 194 & 0.30 \\
Fat & 1,302 & 1,278 & 39 & 0.59 \\
CP & 1,039 & 1,073 & 28 & 0.03 \\
Ash & 220 & 232 & 19 & 0.03 \\
Lactose $^{2}$ & 1,449 & 1,508 & 119 & 0.28 \\
\hline
\end{tabular}

${ }^{1}$ No vitamin supplement $\left(\mathrm{B}_{8}-\mathrm{B}_{12}-\right)$ or a daily supplement of $20 \mathrm{mg}$ of biotin $+500 \mathrm{mg}$ of vitamin $\mathrm{B}_{12}$ per day $\left(\mathrm{B}_{8}+\mathrm{B}_{12}+\right)$.

${ }^{2}$ Calculated as TS $-($ fat $+\mathrm{CP}+$ ash $)$.

tissues were conducted on average postprandial values. Average DMI and milk production during the last $7 \mathrm{~d}$ of each experimental period as well as milk composition were compared. All variables, except for the net fluxes of nutrients across liver and TSP in study 2, were analyzed using the MIXED procedure of SAS (SAS Institute, 2004) according to the following model:

$$
Y_{i j k}=\mu+C_{i}+P_{j}+S_{k}+\varepsilon_{i j k}
$$

where $Y_{i j k}$ is the studied variable, $\mu$ is the overall mean, $C_{i}$ is the cow effect, $P_{j}$ is the period effect, $S_{k}$ is the vitamin supplement effect, and $\varepsilon_{i j k}$ is the residual error. Period and vitamin supplement effects were analyzed as fixed effects and cow as random effect. In study 2, it was not possible to draw blood from the catheter placed in hepatic veins of 2 cows. Therefore, because there was no period effect $(P \geq 0.1)$ on any of the PDV fluxes measured, and in spite of a possible loss of sensitivity of the statistical model, the period effect was removed from the previous model for the analyses of liver and splanchnic fluxes. Fluxes of nutrients across liver and TSP in study 2 were analyzed according to the following model:

$$
Y_{i j}=\mu+C_{i}+S_{j}+\varepsilon_{i j}
$$

where $Y_{i j}$ is the studied variable, $\mu$ is the overall mean, $C_{i}$ is the cow effect, $S_{j}$ is the vitamin supplement effect, and $\varepsilon_{i j}$ is the residual error. Vitamin supplement effect was analyzed as a fixed effect and cow as random effect. Results are reported as least squares means and standard errors of the means. The significance level was defined at $P \leq 0.05$ and trends toward significance were considered at $0.05<P<0.10$.

\section{RESULTS}

\section{Study 1}

Dietary supplements of biotin and vitamin $\mathrm{B}_{12}$ increased $(P=0.04)$ milk production by $1.2 \mathrm{~kg} / \mathrm{d}$ over the control group without any effect on DMI $(P=0.99$; Table 2). There was no effect $(P \geq 0.2)$ of supplementary vitamins on milk composition or on milk yields of TS, fat, and lactose, but the vitamin supplement increased $(P=0.03)$ yields of $\mathrm{CP}$ by $34 \mathrm{~g} / \mathrm{d}$ and ash by $12 \mathrm{~g} / \mathrm{d}$.

There was no effect of treatments on blood flow in the right ruminal artery $(125 \pm 4 \mathrm{~L} / \mathrm{h} ;$ minimum $=112$ $\mathrm{L} / \mathrm{h} ;$ maximum $=149 \mathrm{~L} / \mathrm{h} ; P=0.8)$ and portal vein $(1,350 \pm 103 \mathrm{~L} / \mathrm{h} ;$ minimum $=924 \mathrm{~L} / \mathrm{h} ;$ maximum $=$ $1,698 \mathrm{~L} / \mathrm{h} ; P=0.6)$.

The combined supplement of biotin and vitamin $\mathrm{B}_{12}$ increased arterial concentrations of biotin $(P=0.02)$ and its net appearance across $\operatorname{PDV}(P=0.02)$ and tended to increase TSP flux of the vitamin $(P=0.10$; Tables 3 and 4). The vitamin supplement also increased the appearance of vitamin $\mathrm{B}_{12}$ across PDV $(P=0.04)$ and tended $(P \leq 0.10)$ to increase TSP flux of the vitamin and its arterial concentration. There was no effect $(P \geq 0.21)$ of the vitamin supplement on the flux of the 2 vitamins across the rumen and liver (Table 4 ).

Supplementary biotin and vitamin $\mathrm{B}_{12}$ given together decreased $(P=0.006)$ the appearance of ammonia across PDV. Arterial concentration of urea- $\mathrm{N}$ was lower $(P=0.04)$ in $\mathrm{B}_{8}+\mathrm{B}_{12}+$ cows, but removal of urea- $\mathrm{N}$ by the rumen or PDV as well as its liver and TSP fluxes remained unchanged $(P \geq 0.14$; Tables 3 and 4$)$.

The flux of acetate, i-butyrate, and total VFA across PDV decreased $(P=0.04)$ and the flux of i-butyrate across the rumen tended to decrease $(P=0.10)$ in 
Table 3. Effects of dietary supplements of vitamin $\mathrm{B}_{12}(500 \mathrm{mg})$ and biotin $(20 \mathrm{mg})$ on arterial concentrations of nutrients $(\mathrm{n}=4 \text {; study } 1)^{1}$

\begin{tabular}{lcccc}
\hline Item & $\mathrm{B}_{8}-\mathrm{B}_{12}-$ & $\mathrm{B}_{8}+\mathrm{B}_{12}+$ & $\mathrm{SEM}$ & $P$-value \\
\hline Plasma biotin, $\mathrm{ng} / \mathrm{mL}$ & 1.45 & 1.88 & 0.07 & 0.02 \\
Serum vitamin $\mathrm{B}_{12}, \mathrm{pg} / \mathrm{mL}$ & 222.9 & 817.5 & 107.5 & 0.06 \\
Blood ammonia, $\mathrm{m} M$ & 0.059 & 0.061 & 0.008 & 0.91 \\
Blood urea-N, $\mathrm{m} M$ & 9.32 & 8.81 & 0.82 & 0.04 \\
Blood VFA, $\mathrm{m} M$ & & & & \\
Acetate & 2.20 & 2.27 & 0.07 & 0.06 \\
Propionate & 0.061 & 0.085 & 0.005 & 0.04 \\
I-butyrate & 0.011 & 0.004 & 0.002 & 0.06 \\
Butyrate & 0.033 & 0.033 & 0.003 & 0.95 \\
Total & 2.30 & 2.39 & 0.07 & 0.05 \\
Plasma glucose, $\mathrm{m} M$ & 3.66 & 3.67 & 0.09 & 0.91 \\
Blood lactate, $\mathrm{m} M$ & 0.48 & 0.55 & 0.01 & 0.02 \\
Blood BHBA, $\mathrm{m} M$ & 0.52 & 0.51 & 0.05 & 0.57 \\
\hline
\end{tabular}

${ }^{1}$ No vitamin supplement $\left(\mathrm{B}_{8}-\mathrm{B}_{12}-\right)$ or a daily supplement of $20 \mathrm{mg}$ of biotin $+500 \mathrm{mg}$ of vitamin $\mathrm{B}_{12}$ per day $\left(\mathrm{B}_{8}+\mathrm{B}_{12}+\right)$.

$\mathrm{B}_{8}+\mathrm{B}_{12}+$ cows, but there was no other treatment effect $(P \geq 0.11)$ on VFA flux across the rumen, liver, and TSP (Table 4).

The combined supplement of vitamins decreased the appearance of lactate across the rumen $(P=0.03)$ but increased its arterial concentration $(P=0.02$; Tables 3 and 4$)$. The net liver flux of BHBA tended to increase $(P=0.09)$ with the supplement, whereas the vitamin supplement had no effect $(P \geq 0.8)$ on arterial concentration and net flux of glucose across the studied tissues.

\section{Study 2}

Milk production and composition, yields of milk components, and DMI were not different $(P \geq 0.2)$ when cows were fed supplementary vitamin $\mathrm{B}_{12}$ alone or combined with biotin (Table 5), except for milk lactose yield, which was higher $(P=0.003)$ when cows were fed vitamin $\mathrm{B}_{12}$ alone.

There was no effect of treatments on blood flow in the right ruminal artery $(122 \pm 4 \mathrm{~L} / \mathrm{h} ;$ minimum $=112$ $\mathrm{L} / \mathrm{h} ;$ maximum $=147 \mathrm{~L} / \mathrm{h} ; P=0.7)$ and portal vein $(1,261 \pm 93 \mathrm{~L} / \mathrm{h} ;$ minimum $=837 \mathrm{~L} / \mathrm{h} ;$ maximum $=$ $1,565 \mathrm{~L} / \mathrm{h} ; P=0.8)$.

Supplementary biotin and vitamin $\mathrm{B}_{12}$ given together increased $(P=0.04)$ arterial concentration of biotin and tended to increase $(P \leq 0.09)$ the net flux of the vitamin across PDV, liver, and TSP tissues (Tables 6 and 7). Arterial concentration of vitamin $\mathrm{B}_{12}$ and its net flux across rumen, PDV, liver, and TSP did not differ $(P \geq 0.12)$ between the 2 vitamin supplements.

The appearance of ammonia across PDV as well as its removal by the liver were reduced $(P \leq 0.03$; Table 7$)$ in $\mathrm{B}_{8}+\mathrm{B}_{12}+$ cows compared with $\mathrm{B}_{8}-\mathrm{B}_{12}+$ cows. Urea$\mathrm{N}$ removal by the PDV tissues increased $(P=0.02)$ in $\mathrm{B}_{8}+\mathrm{B}_{12}+$ cows, whereas blood arterial concentration of urea-N decreased ( $P=0.008$; Tables 6 and 7$)$.
Except for a tendency $(P=0.06)$ to an increased appearance of butyrate across the rumen with $\mathrm{B}_{8}+\mathrm{B}_{12}+$, net appearance of VFA across rumen and PDV did not differ $(P \geq 0.11)$ between the vitamin supplements (Table 7). The combined supplement of vitamins increased $(P=0.03)$ removal of i-butyrate by the liver and decreased $(P=0.03)$ TSP flux of propionate (Table 7$)$.

Arterial concentrations of glucose was lower $(P=$ $0.02)$ in $\mathrm{B}_{8}+\mathrm{B}_{12}+$ than $\mathrm{B}_{8}-\mathrm{B}_{12}+$ cows. There was a net appearance of glucose across PDV tissues with $\mathrm{B}_{8}-\mathrm{B}_{12}+$ but a net removal with $\mathrm{B}_{8}+\mathrm{B}_{12}+(P=0.02)$; TSP flux of glucose was also lower $(P=0.02)$ when the cows were fed the 2 vitamins together. Net appearance of BHBA from the liver and its arterial concentration tended to increase $(P \leq 0.10)$ with the combined supplement of biotin and vitamin $\mathrm{B}_{12}$ compared with vitamin $\mathrm{B}_{12}$ given alone (Tables 6 and 7 ). There was no treatment effect $(P \geq 0.3)$ on arterial concentration and net flux of lactate across the studied tissues.

\section{DISCUSSION}

\section{Production Data}

In study 1 , the combined supplement of biotin and vitamin $\mathrm{B}_{12}$ increased milk production in cows compared with cows fed no vitamin supplement, but it had no effect in study 2 when compared with cows fed vitamin $\mathrm{B}_{12}$ alone, suggesting that the addition of vitamin $\mathrm{B}_{12}$ was responsible for this increment. Nevertheless, comparisons between the 2 present studies could be misleading because cows produced more than $30 \mathrm{~kg} / \mathrm{d}$ in study 1 whereas, as lactation progressed, milk production was lower in study 2. Supplementary biotin is generally reported to increase milk production in cows producing more than $30 \mathrm{~kg} / \mathrm{d}$, but not in low-producing cows (Cooke and Brumby, 1982; Bonomi et al., 1996; Midla et al., 1998; Fitzgerald et al., 2000; Zimmerly 
Table 4. Effects of dietary supplements of vitamin $B_{12}(500 \mathrm{mg})$ and biotin $(20 \mathrm{mg})$ on net flux of nutrients across the right rumen wall, portal-drained viscera, splanchnic tissues, and liver (study 1 )

\begin{tabular}{|c|c|c|c|c|}
\hline Item, $\mathrm{mmol} / \mathrm{h}$ unless noted & $\mathrm{B}_{8}-\mathrm{B}_{12}-$ & $\mathrm{B}_{8}+\mathrm{B}_{12}+$ & SEM & $P$-value \\
\hline \multicolumn{5}{|c|}{ Flux across right rumen wall $(\mathrm{n}=4)$} \\
\hline Plasma biotin, $\mu \mathrm{g} / \mathrm{h}$ & -9.6 & -0.3 & 2.5 & 0.21 \\
\hline Serum vitamin $B_{12}, \mu g / h$ & -12.7 & 3.2 & 11.5 & 0.46 \\
\hline Blood ammonia & 137.5 & 108.2 & 9.6 & 0.26 \\
\hline Blood urea-N & -56.9 & -61.6 & 10.6 & 0.79 \\
\hline \multicolumn{5}{|l|}{ Blood VFA } \\
\hline Acetate & 630.4 & 542.3 & 27.7 & 0.22 \\
\hline Propionate & 208.6 & 182.7 & 12.4 & 0.35 \\
\hline I-butyrate & 5.9 & 4.8 & 0.5 & 0.10 \\
\hline Butyrate & 35.5 & 29.3 & 2.6 & 0.18 \\
\hline Total & 883.4 & 759.1 & 40.2 & 0.24 \\
\hline Plasma glucose & -2.3 & -1.5 & 4.3 & 0.91 \\
\hline Blood lactate & 26.9 & 25.0 & 1.6 & 0.03 \\
\hline Blood BHBA & 53.2 & 46.0 & 3.7 & 0.36 \\
\hline \multicolumn{5}{|c|}{ Flux across portal-drained viscera $(\mathrm{n}=4)$} \\
\hline Plasma biotin, $\mu \mathrm{g} / \mathrm{h}$ & -67.2 & 135.6 & 32.3 & 0.02 \\
\hline Serum vitamin $B_{12}, \mu \mathrm{g} / \mathrm{h}$ & 24.4 & 146.2 & 27.8 & 0.04 \\
\hline Blood ammonia & 677.9 & 568.8 & 84.4 & 0.006 \\
\hline Blood urea-N & -583.8 & -686.3 & 197.1 & 0.73 \\
\hline \multicolumn{5}{|l|}{ Blood VFA } \\
\hline Acetate & $2,726.4$ & $2,407.7$ & 164.1 & 0.0006 \\
\hline Propionate & $1,031.1$ & 974.1 & 120.5 & 0.38 \\
\hline I-butyrate & 34.4 & 26.9 & 5.2 & 0.04 \\
\hline Butyrate & 213.4 & 187.1 & 28.6 & 0.11 \\
\hline Total & $4,005.3$ & $3,695.8$ & 238.1 & 0.01 \\
\hline Plasma glucose & -17.1 & -29.9 & 56.0 & 0.87 \\
\hline Blood lactate & 122.5 & 101.0 & 14.4 & 0.40 \\
\hline Blood BHBA & 162.7 & 136.1 & 19.2 & 0.16 \\
\hline \multicolumn{5}{|l|}{ Net liver flux $(\mathrm{n}=4)$} \\
\hline Plasma biotin, $\mu \mathrm{g} / \mathrm{h}$ & 119.8 & 113.3 & 57.9 & 0.95 \\
\hline Serum vitamin $\mathrm{B}_{12}, \mu \mathrm{g} / \mathrm{h}$ & -34.5 & -40.9 & 23.4 & 0.64 \\
\hline Blood ammonia & -782.7 & -592.9 & 78.1 & 0.31 \\
\hline Blood urea-N & 972.5 & 870.5 & 199.3 & 0.76 \\
\hline \multicolumn{5}{|l|}{ Blood VFA } \\
\hline Acetate & 193.7 & 362.6 & 141.3 & 0.53 \\
\hline Propionate & $-1,089.8$ & -939.4 & 134.0 & 0.55 \\
\hline I-butyrate & -38.3 & -31.2 & 5.7 & 0.35 \\
\hline Butyrate & -181.3 & -168.0 & 29.1 & 0.15 \\
\hline Total & $-1,150.8$ & -776.0 & 254.7 & 0.46 \\
\hline Plasma glucose & 805.2 & 827.3 & 50.9 & 0.79 \\
\hline Blood lactate & -77.9 & -41.7 & 34.5 & 0.17 \\
\hline Blood BHBA & 194.3 & 239.7 & 31.1 & 0.09 \\
\hline \multicolumn{5}{|c|}{ Flux across splanchnic tissues $(\mathrm{n}=4)$} \\
\hline Plasma biotin, $\mu \mathrm{g} / \mathrm{h}$ & 16.5 & 225.8 & 28.3 & 0.10 \\
\hline Serum vitamin $\mathrm{B}_{12}, \mu \mathrm{g} / \mathrm{h}$ & -14.8 & 126.7 & 52.3 & 0.10 \\
\hline Blood ammonia & -31.9 & -23.5 & 16.8 & 0.77 \\
\hline Blood urea-N & 352.9 & 169.4 & 64.2 & 0.14 \\
\hline \multicolumn{5}{|l|}{ Blood VFA } \\
\hline Acetate & $3,302.6$ & $2,784.7$ & 290.8 & 0.40 \\
\hline Propionate & 59.8 & 35.0 & 14.7 & 0.37 \\
\hline I-butyrate & -1.7 & -3.2 & 3.0 & 0.77 \\
\hline Butyrate & 31.0 & 20.1 & 6.6 & 0.43 \\
\hline Total & $3,390.5$ & $2,836.6$ & 301.6 & 0.39 \\
\hline Plasma glucose & 804.7 & 789.4 & 119.2 & 0.87 \\
\hline Blood lactate & 53.3 & 58.5 & 34.9 & 0.84 \\
\hline Blood BHBA & 365.6 & 377.2 & 42.0 & 0.21 \\
\hline
\end{tabular}

${ }^{1}$ No vitamin supplement $\left(\mathrm{B}_{8}-\mathrm{B}_{12}-\right)$ or a daily supplement of $20 \mathrm{mg}$ of biotin $+500 \mathrm{mg}$ of vitamin $\mathrm{B}_{12}$ per day $\left(\mathrm{B}_{8}+\mathrm{B}_{12}+\right)$.

and Weiss, 2001; Bergsten et al., 2003; Majee et al., 2003; Rosendo et al., 2004; Ferreira and Weiss, 2007; Ferreira et al., 2007; Reynolds et al., 2007; Enjalbert et al., 2008). The effect of supplementary biotin on milk composition is generally limited, but increases in milk yields of protein had been reported (Zimmerly and 
Table 5. Effects of dietary supplements of vitamin $B_{12}(500 \mathrm{mg})$ with or without biotin $(20 \mathrm{mg})$ on milk production and composition $(\mathrm{n}=4 ; \text { study } 2)^{1}$

\begin{tabular}{lcccc}
\hline Item & $\mathrm{B}_{8}-\mathrm{B}_{12}+$ & $\mathrm{B}_{8}+\mathrm{B}_{12}+$ & $\mathrm{SEM}$ & $P$-value \\
\hline Milk production, kg/d & 28.0 & 27.1 & 2.7 & 0.28 \\
DMI, kg/d & 22.5 & 22.5 & 0.5 & 0.81 \\
Milk composition, g/kg & & & & \\
TS & 132.5 & 133.5 & 5.4 & 0.57 \\
Fat & 43.2 & 44.4 & 2.9 & 0.46 \\
CP & 35.8 & 34.9 & 2.3 & 0.22 \\
Ash & 7.3 & 7.4 & 0.1 & 0.37 \\
Lactose & 46.2 & 46.8 & 0.6 & 0.62 \\
Milk component yield, g/d & & & & 0.26 \\
TS & 3,664 & 3,579 & 184 & 0.99 \\
Fat & 1,185 & 1,185 & 51 & 0.25 \\
CP & 986 & 930 & 46 & 0.57 \\
Ash & 203 & 199 & 20 & 0.003 \\
Lactose ${ }^{2}$ & 1,290 & 1,265 & 57 & \\
${ }^{1}$ Daily supplements of $500 \mathrm{mg}$ of vitamin $\mathrm{B}_{12}\left(\mathrm{~B}_{8}-\mathrm{B}_{12}+\right)$ or $20 \mathrm{mg}$ of biotin $+500 \mathrm{mg}$ of vitamin $\mathrm{B}_{12}$ \\
(B $_{8}+\mathrm{B}_{12}+$ ). \\
${ }^{2}$ Calculated as TS - (fat $+\mathrm{CP}+$ ash).
\end{tabular}

Weiss, 2001; Majee et al., 2003; Ferreira et al., 2007). Blends of B-vitamins including vitamin $\mathrm{B}_{12}$, at doses 500 and 1,000 times lower than the amount used in the present studies given in addition to biotin supplements, had no effect on milk production or composition compared with biotin given alone (Majee et al., 2003).

\section{Blood Flow}

Rémond et al. (1993) reported that in sheep, blood flows in the right and left ruminal arteries are generally equal, although in some animals, blood flows in the right ruminal artery could be greater. In dairy cows, however, variations between the areas irrigated by the right and left ruminal arteries among animals seem to be larger than in sheep. In the present experiment, blood flow in the right ruminal artery varied between 7.4 and $13.0 \mathrm{~L} / \mathrm{h}$ for the 4 cows. This variability among animals is confirmed by a later study recording blood flow in the right and left ruminal arteries of 5 lactating dairy cows. Averaged blood flow recorded for the left ruminal artery represented $90 \pm 10 \%$ of the flow in the right ruminal artery, but this ratio varied from 68 to $124 \%$ among the 5 studied cows (our unpublished data). In the present experiment, there was no correlation between blood flows in the right ruminal artery and the portal vein $(\mathrm{r}=0.03 ; P=0.91)$.

Rémond et al. (1998) demonstrated that in sheep, portal blood flow measured using A-series flow probes, like those used in the present studies, gave similar values as blood flow measured with an indicator dilution method. One should keep in mind that, in the present experiment, blood flow in the portal vein was measured and liver and TSP blood flows were calculated as described previously, whereas in experiments reported by Reynolds (1995), using indicator dilution methods, PDV

Table 6. Effects of dietary supplements of vitamin $B_{12}(500 \mathrm{mg})$ with or without biotin $(20 \mathrm{mg})$ on arterial concentrations $(\mathrm{n}=4 \text {; study } 2)^{1}$

\begin{tabular}{|c|c|c|c|c|}
\hline Item & $\mathrm{B}_{8}-\mathrm{B}_{12}+$ & $\mathrm{B}_{8}+\mathrm{B}_{12}+$ & SEM & $P$-value \\
\hline Plasma biotin, $\mathrm{ng} / \mathrm{mL}$ & 1.58 & 1.68 & 0.07 & 0.04 \\
\hline Serum vitamin $\mathrm{B}_{12}, \mathrm{pg} / \mathrm{mL}$ & 605.1 & 758.5 & 147.0 & 0.12 \\
\hline Blood ammonia, $\mathrm{m} M$ & 0.075 & 0.073 & 0.005 & 0.69 \\
\hline Blood urea- $\mathrm{N}, \mathrm{m} M$ & 10.46 & 9.34 & 1.06 & 0.008 \\
\hline \multicolumn{5}{|l|}{ Blood VFA, mM } \\
\hline Acetate, & 2.05 & 2.02 & 0.09 & 0.79 \\
\hline Propionate & 0.082 & 0.066 & 0.016 & 0.52 \\
\hline I-butyrate & 0.015 & 0.011 & 0.001 & 0.04 \\
\hline Butyrate & 0.025 & 0.027 & 0.002 & 0.46 \\
\hline Total & 2.17 & 2.12 & 0.11 & 0.72 \\
\hline Plasma glucose, $\mathrm{m} M$ & 3.74 & 3.61 & 0.10 & 0.02 \\
\hline Blood lactate, $\mathrm{m} M$ & 0.55 & 0.55 & 0.02 & 0.99 \\
\hline Blood BHBA, m $M$ & 0.44 & 0.50 & 0.08 & 0.07 \\
\hline
\end{tabular}


Table 7. Effects of dietary supplements of vitamin $B_{12}(500 \mathrm{mg})$ with or without biotin $(20 \mathrm{mg})$ on net flux of nutrients across the right rumen wall, portal-drained viscera, splanchnic tissues, and liver (study 2$)^{1}$

\begin{tabular}{|c|c|c|c|c|}
\hline Item, $\mathrm{mmol} / \mathrm{h}$ unless noted & $\mathrm{B}_{8}-\mathrm{B}_{12}+$ & $\mathrm{B}_{8}+\mathrm{B}_{12}+$ & SEM & $P$-value \\
\hline \multicolumn{5}{|c|}{ Flux across right rumen wall $(\mathrm{n}=3)$} \\
\hline Plasma biotin, $\mu \mathrm{g} / \mathrm{h}$ & -8.9 & 1.8 & 4.0 & 0.13 \\
\hline Serum vitamin $B_{12}, \mu \mathrm{g} / \mathrm{h}$ & 5.7 & 4.0 & 2.9 & 0.75 \\
\hline Blood ammonia & 112.3 & 102.5 & 10.9 & 0.65 \\
\hline Blood urea-N & -58.4 & -24.5 & 28.4 & 0.50 \\
\hline \multicolumn{5}{|l|}{ Blood VFA } \\
\hline Acetate & 534.7 & 507.1 & 5.3 & 0.17 \\
\hline Propionate & 202.7 & 166.3 & 31.3 & 0.53 \\
\hline I-butyrate & 4.5 & 4.6 & 0.5 & 0.76 \\
\hline Butyrate & 28.6 & 33.8 & 2.3 & 0.06 \\
\hline Total & 770.5 & 711.8 & 34.6 & 0.45 \\
\hline Plasma glucose & -1.3 & -0.8 & 1.5 & 0.87 \\
\hline Blood lactate & 27.1 & 22.0 & 2.6 & 0.26 \\
\hline Blood BHBA & 43.5 & 46.2 & 0.9 & 0.20 \\
\hline \multicolumn{5}{|c|}{ Flux across portal-drained viscera $(\mathrm{n}=4)$} \\
\hline Plasma biotin, $\mu \mathrm{g} / \mathrm{h}$ & -22.0 & 289.4 & 62.1 & 0.07 \\
\hline Serum vitamin $B_{12}, \mu \mathrm{g} / \mathrm{h}$ & 42.1 & 32.1 & 19.6 & 0.75 \\
\hline Blood ammonia & 611.1 & 533.3 & 77.7 & 0.03 \\
\hline Blood urea-N & -314.3 & -530.5 & 158.4 & 0.02 \\
\hline \multicolumn{5}{|l|}{ Blood VFA } \\
\hline Acetate & $1,949.5$ & $1,997.9$ & 171.3 & 0.55 \\
\hline Propionate & 868.9 & 793.4 & 103.6 & 0.31 \\
\hline I-butyrate & 23.2 & 23.9 & 3.2 & 0.72 \\
\hline Butyrate & 139.0 & 154.5 & 15.9 & 0.11 \\
\hline Total & $2,980.7$ & $2,969.6$ & 273.5 & 0.61 \\
\hline Plasma glucose & 39.9 & -50.6 & 54.2 & 0.02 \\
\hline Blood lactate & 122.9 & 115.1 & 18.6 & 0.68 \\
\hline Blood BHBA & 127.9 & 121.9 & 16.2 & 0.71 \\
\hline \multicolumn{5}{|l|}{ Net liver flux $(\mathrm{n}=2)$} \\
\hline Plasma biotin, $\mu \mathrm{g} / \mathrm{h}$ & 145.2 & 222.0 & 46.1 & 0.09 \\
\hline Serum vitamin $B_{12}, \mu \mathrm{g} / \mathrm{h}$ & -13.0 & -33.3 & 42.9 & 0.75 \\
\hline Blood ammonia & -821.2 & -588.8 & 36.8 & 0.006 \\
\hline Blood urea-N & 1.259 .5 & $1,695.9$ & 231.9 & 0.41 \\
\hline \multicolumn{5}{|l|}{ Blood VFA } \\
\hline Acetate & 555.7 & 383.6 & 177.0 & 0.30 \\
\hline Propionate & -940.4 & -790.2 & 148.7 & 0.40 \\
\hline I-butyrate & -19.8 & -26.5 & 4.1 & 0.03 \\
\hline Butyrate & -130.2 & -155.8 & 18.1 & 0.28 \\
\hline Total & -534.8 & -588.9 & 310.8 & 0.82 \\
\hline Plasma glucose & 905.1 & 927.2 & 49.5 & 0.61 \\
\hline Blood lactate & -9.8 & -138.3 & 74.1 & 0.44 \\
\hline Blood BHBA & 224.5 & 290.4 & 45.1 & 0.10 \\
\hline \multicolumn{5}{|c|}{ Flux across splanchnic tissues $(\mathrm{n}=2)$} \\
\hline Plasma biotin, $\mu \mathrm{g} / \mathrm{h}$ & 116.9 & 446.3 & 26.3 & 0.07 \\
\hline Serum vitamin $B_{12}, \mu \mathrm{g} / \mathrm{h}$ & 64.0 & 22.9 & 44.3 & 0.35 \\
\hline Blood ammonia & -22.7 & 3.2 & 15.0 & 0.38 \\
\hline Blood urea-N & 706.9 & 848.8 & 125.6 & 0.57 \\
\hline \multicolumn{5}{|l|}{ Blood VFA } \\
\hline Acetate & $2,565.8$ & $2,648.2$ & 187.8 & 0.77 \\
\hline Propionate & 50.0 & 30.2 & 8.0 & 0.03 \\
\hline I-butyrate & 1.3 & -2.1 & 0.6 & 0.17 \\
\hline Butyrate & 12.6 & 20.4 & 4.1 & 0.20 \\
\hline Total & $2,629.6$ & $2,696.7$ & 197.2 & 0.81 \\
\hline Plasma glucose & $1,013.0$ & 764.8 & 9.7 & 0.02 \\
\hline Blood lactate & 111.8 & 27.0 & 77.0 & 0.48 \\
\hline Blood BHBA & 374.5 & 424.4 & 26.0 & 0.34 \\
\hline
\end{tabular}

and TSP blood flows were measured and liver blood flow was calculated. In the present experiment, liver blood flow represents only 61 to $64 \%$ of the expected liver blood flow calculated according to the equation by Reynolds (1995). However, calculated according to the equations described by Reynolds (1995) and 
notwithstanding the treatment effects, liver removal of propionate in the 2 studies ranged between 70 and $94 \%$ of the calculated values and liver release of glucose ranged between 87 and $103 \%$ of these values. Therefore, although lower than the expected values but based on liver fluxes of glucose and propionate, liver blood flows measured in the present studies seem reasonable.

\section{Vitamins}

There was no appearance of vitamin $\mathrm{B}_{12}$ through the rumen wall, even in cows fed the vitamin supplements. A positive flux of vitamin $B_{12}$ across the rumen wall of cows has already been observed after a single ruminal bolus of the vitamin but at a dose (7.8 g; Girard et al., 2001) greater than that used in the present experiment $(500 \mathrm{mg} / \mathrm{d}$, or $42 \mathrm{mg} / \mathrm{meal})$. In study 1 , the net PDV release of vitamin $\mathrm{B}_{12}$ per day was $2.6 \mathrm{mg}$ greater in $\mathrm{B}_{8}+\mathrm{B}_{12}+$ cows than in $\mathrm{B}_{8}-\mathrm{B}_{12^{-}}$cows, representing $0.5 \%$ of the dose ingested. This proportion is of the same magnitude as that previously observed by Girard et al. (2001), who reported that $0.3 \%$ of a dietary supplement of $500 \mathrm{mg}$ of cyanocobalamin given in a single dose was released from the PDV during the following $24 \mathrm{~h}$. Ingestion of supplementary vitamin $\mathrm{B}_{12}$ increased the TSP flux of the vitamin by $3.2 \mathrm{mg} / \mathrm{d}$ as well as its arterial concentration, but without any significant effect on its uptake by the liver compared with unsupplemented cows.

In the 2 studies, the flux of biotin across the rumen wall was not different from zero. However, there was a net removal of biotin by the gastrointestinal walls in cows not fed supplementary biotin, whereas in $\mathrm{B}_{8}+\mathrm{B}_{12}+$ cows, there was a net appearance of 4.9 to $7.5 \mathrm{mg} / \mathrm{d}$ of the vitamin through PDV. These amounts represented 25 to $38 \%$ of the biotin supplement served daily. Santschi et al. (2005b) reported that, in cows fed a daily supplement of $20 \mathrm{mg}$ of biotin, $37 \%$ of the amount reaching the duodenal cannula disappeared in the small intestine. As observed for vitamin $\mathrm{B}_{12}$, TSP flux and arterial concentration of biotin were increased in cows fed the vitamin supplement. The flux of biotin in the liver was similar in cows fed no vitamin supplement or the 2 vitamins together, but it tended to be decreased when the cows were fed vitamin $\mathrm{B}_{12}$ alone, possibly indicating an increased need of hepatic tissues for biotin.

\section{Nitrogen Metabolism}

Reynolds et al. (2007) observed that supplementary biotin given alone, at the dose used in the present studies, increased net PDV release of ammonia, whereas Bonomi et al. (1996) observed no effect of biotin supplements on blood concentrations of urea-N. However, in the present experiment, the combined supplement of biotin and vitamin $\mathrm{B}_{12}$ decreased the release of ammonia across PDV and its uptake by the liver as well as the arterial concentrations of urea-N. Ammonia absorbed from the PDV is mostly from microbial fermentation of dietary protein, although some of it is derived from urea transferred to the lumen of the gastrointestinal tract via blood and saliva or tissue metabolism (Huntington, 1989). Because feed intake did not differ between treatments within each study, differences in release of ammonia across PDV, in spite of an increased removal of urea- $\mathrm{N}$ by gastrointestinal walls of $\mathrm{B}_{8}+\mathrm{B}_{12}+$ cows in study 2 , demonstrated that the combined vitamin supplement altered nitrogen metabolism in rumen compared with cows fed no biotin supplements. This decreased PDV flux of ammonia could be caused by either an increased utilization for microbial protein synthesis or, on the contrary, a reduced ruminal degradation of dietary proteins.

\section{Energy Metabolism}

Bonomi et al. (1996) observed a decrease in blood concentration of acetate in cows fed supplementary biotin alone. However, most studies reported no marked effect of supplementary biotin given alone on molar concentrations of VFA in ruminal fluid (Zimmerly and Weiss, 2001; Majee et al., 2003; Ferreira et al., 2007) or on PDV, TSP, and liver flux of VFA (Reynolds et al., 2007). In the present experiment, the combined supplement of biotin and vitamin $\mathrm{B}_{12}$ decreased the release of most individual and total VFA, except propionate, across PDV compared with $\mathrm{B}_{8}-\mathrm{B}_{12}-$ cows (study 1 ), but had no such effect compared with $\mathrm{B}_{8}-\mathrm{B}_{12}+$ cows (study 2). This observation, in combination with observations on nitrogen metabolism described previously, further supports the hypothesis that a dietary supplement of the 2 vitamins altered ruminal fermentation, although for VFA flux specifically, the effect was more likely caused by vitamin $\mathrm{B}_{12}$ supplements. Moreover, the release of VFA across PDV was $20 \%$ lower in study 2 than in study 1 despite a DMI difference of less than $3 \%$; this further reduction of the VFA flux is possibly caused by a carryover effect of the vitamin supplementation given in study 1 on ruminal microflora.

Some studies observed an increase in plasma glucose with biotin supplements given alone (Bonomi et al., 1996; Rosendo et al., 2004), but most studies observed no effect (Zimmerly and Weiss, 2001; Majee et al., 2003; Reynolds et al., 2007). Graulet et al. (2007) observed that a dietary supplement of vitamin $\mathrm{B}_{12}$ increased plasma glucose in cows also fed supplementary folic acid but had no effect in cows fed vitamin $B_{12}$ supplement 
alone. In study 1 , the combined supplement of biotin and vitamin $\mathrm{B}_{12}$ had no effect on glucose metabolism although it tended to increase the release of BHBA by the liver; the latter could be caused by an augmentation of the demand for energy to sustain the increased milk production observed with this treatment. In study 2 , however, compared with the 2 vitamins given together, vitamin $\mathrm{B}_{12}$ alone seems to improve energy metabolism. It increased glucose release from PDV and TSP and tended to decrease liver release of BHBA. Arterial concentrations of glucose and BHBA followed the same trends. The increased PDV and TSP fluxes and arterial concentrations of glucose in $\mathrm{B}_{8}-\mathrm{B}_{12}+$ cows probably explained the minor augmentation of the milk yield of lactose observed in these cows.

Early works indicated that, in sheep, a large proportion of propionate is metabolized in rumen wall whereas, in cattle, this proportion is only 5 to $15 \%$ (Elliot, 1979). However, using radioisotopes, Seal and Parker (1994) demonstrated that propionate is extensively metabolized in the rumen wall of steers where it enters the gluconeogenic pathway, drastically reducing glucose utilization by gastrointestinal tissues and leaving more glucose available for the other tissues. Utilization of propionate requires the transformation of propionate into succinyl-CoA through 4 reactions; 2 of these reactions use biotin and vitamin $\mathrm{B}_{12}$ as coenzymes. Supplementary biotin given to dairy cows increased the activity of pyruvate carboxylase, the enzyme essential for the carboxylation of pyruvate in oxaloacetate in liver, but had no effect on propionyl-CoA activity; because of the importance of propionate metabolism in lactating dairy cows, propionyl-CoA has a higher priority for biotin than pyruvate carboxylase (Ferreira and Weiss, 2007). However, there is no obvious explanation for the fact that in the present experiment, supplementary vitamin $\mathrm{B}_{12}$ given alone decreased removal of glucose from the gastrointestinal walls more efficiently than when given with biotin.

\section{CONCLUSIONS}

A dietary supplement of biotin and vitamin $B_{12}$, at the doses used in the present experiment, seems to affect ruminal fermentation, decreasing the amounts of ammonia and VFA reaching the portal blood. Nevertheless, in study 1, milk production and milk protein yield were increased with this supplement, possibly because with the diet used in the present studies, AA composition of the dietary protein not degraded in rumen completed the AA profile of microbial protein to match more closely dairy cow requirements for milk protein synthesis. However, the increased release of BHBA from the liver and arterial concentrations seem to indicate that increasing milk yield while decreasing PDV flux of VFA put some strain on energy metabolism. In study 2 , even if DMI was similar for the 2 treatments, supplementary vitamin $\mathrm{B}_{12}$ given alone increased glucose appearance from PDV and TSP compared with the 2 vitamins given together. This increase probably explained the minor milk lactose yield increment observed in cows fed only vitamin $B_{12}$ supplement. With the diet used in the present experiment, a dietary supplementation in biotin and vitamin $\mathrm{B}_{12}$ changed the net PDV flux of nutrients, probably through alterations of the rumen fermentations, whereas vitamin $\mathrm{B}_{12}$ supplement alone mostly modified glucose metabolism within the gastrointestinal walls. However, the vitamin supplements had limited effects on hepatic metabolism. Therefore, under the conditions of the present experiment, responses of lactational performance to vitamin supplementations were likely caused by changes in nutrient supply from the gastrointestinal tract. However, with the design used, effects on metabolism of extrahepatic tissues cannot be ruled out.

\section{ACKNOWLEDGMENTS}

The authors acknowledge the Dairy Farmers of Canada (Ottawa, Ontario, Canada) and the Matching Investment Initiative of Agriculture and Agri-Food Canada (Ottawa, Ontario, Canada) for financial support. The authors are also grateful to Marie-Ève Bouchard and Étienne Viens for animal care, Chrystiane Plante and Véronique Roy for technical assistance, and Steve Méthot for statistical advice (all from Agriculture and Agri-Food Canada, Sherbrooke, Québec, Canada). Supplementary vitamin $\mathrm{B}_{12}$ (cyanocobalamin) was kindly provided by Adisseo France SAS (Antony, France) and biotin provided by Hoffmann-LaRoche (Cambridge, Ontario, Canada).

\section{REFERENCES}

Agriculture Canada. 1990. Recommended Code of Practice for Care and Handling of Dairy Cattle. Publ. no. 1853/E. Agriculture Canada, Ottawa, Ontario, Canada.

Association of Official Analytical Chemists. 2000. Official Methods of Analysis. 17th ed. AOAC, Arlington, VA.

Bergmeyer, H. U., and H. A. Beutler. 1985. Methods of Enzymatic Analysis. 3rd ed. Verlag Chemie, Deerfield Beach, FL.

Bergsten, C., P. R. Greenough, J. M. Gay, W. M. Seymour, and C. C. Gay. 2003. Effects of biotin supplementation on performance and claw lesions on a commercial dairy farm. J. Dairy Sci. 86:39533962 .

Bonomi, A., A. Quarantelli, A. Sabbioni, and P. Superchi. 1996. L'integrazione delle razioni per le bovine da latte con biotina in forma rumino-protetta. Effeti sull'efficienza produttiva e riporduttiva (contributo sperimentale) [Dairy cattle ration integration with rumen-protected biotin. Effects on production and reproductive efficiency (experimental contribution)]. La Rivista di Scienza dell'Alimentazione 25:49-68. 
Canadian Council on Animal Care. 1993. Guide to the Care and Use of Experimental Animals. 2nd ed. Vol. 1. E. D. Rolfert, B. M. Cross, and A. A. McWilliam, ed. Canadian Council on Animal Care, Ottawa, Ontario, Canada.

Cooke, B. C., and P. E. Brumby. 1982. Biotin-A dairy herd feeding trial. Pages 21-26 in Proceedings of the Roche Vitamin Symposium, London, UK. Hoffmann-La Roche \& Co. AG, Basel, Switzerland.

Elliot, J. M. 1979. Propionate metabolism and vitamin $\mathrm{B}_{12}$. Pages 485-503 in Digestive Physiology and Metabolism in Ruminants. Y. Ruckebush and P. Thivend, ed. AVI Publishing Co. Inc., Westport, CT.

Enjalbert, F., M. C. Micot, and A. J. Packington. 2008. Effects of peripartum biotin supplementation of dairy cows on milk production and milk composition with emphasis on fatty acids profile. Livest. Sci. 114:287-295.

Ferreira, G., and W. P. Weiss. 2007. Effects of biotin on activity and gene expression of biotin-dependent carboxylases in the liver of dairy cows. J. Dairy Sci. 90:1460-1466.

Ferreira, G., W. P. Weiss, and L. B. Willett. 2007. Changes in measures of biotin status do not reflect milk yield responses when dairy cows are fed supplemental biotin. J. Dairy Sci. 90:1452-1459.

Fitzgerald, T., B. W. Norton, R. Elliott, H. Podlich, and O. L Svendsen. 2000. The influence of long-term supplementation with biotin on the prevention of lameness in pasture fed dairy cows. J. Dairy Sci. 83:338-344.

Girard, C. L., H. Lapierre, A. Desrochers, C. Benchaar, J. J. Matte, and D. Rémond. 2001. Net flux of folates and vitamin $B_{12}$ through the gastrointestinal tract and the liver of lactating dairy cows. Br. J. Nutr. 86:707-715.

Girard, C. L., H. Lapierre, J. J. Matte, and G. E. Lobley. 2005. Effects of dietary supplements of folic acid and rumen-protected methionine on lactational performance and folate metabolism of dairy cows. J. Dairy Sci. 88:660-670.

Girard, C. L., and J. J. Matte. 1988. Blood serum concentrations of folates and vitamin $B_{12}$ during growth period of white veal calves. Can. J. Anim. Sci. 68:455-460.

Girard, C. L., and J. J. Matte. 2006. Impact of B-vitamin supply on major metabolic pathways of lactating dairy cows. Can. J. Anim. Sci. $86: 213-220$.

Graulet, B., J. J. Matte, A. Desrochers, L. Doepel, M. F. Palin, and C. L. Girard. 2007. Effects of dietary supplements of folic acid and vitamin $\mathrm{B}_{12}$ on metabolism of dairy cows in early lactation. J. Dairy Sci. 90:3442-3455.

Hocquette, J. F., and D. Bauchart. 1999. Intestinal absorption, blood transport and hepatic and muscle metabolism of fatty acids in preruminant and ruminant animals. Reprod. Nutr. Dev. 39:2748.

Huntington, G. B. 1984. Net absorption of glucose and nitrogenous compounds by lactating Holstein cows. J. Dairy Sci. 67:19191927.

Huntington, G. B. 1989. Hepatic urea synthesis and site and rate of urea removal from blood of beef steers fed alfalfa hay or high concentrate diet. Can. J. Anim. Sci. 69:215-223.

Le Grusse, J., and B. Watier. 1993. Les vitamines. Données Biochimiques, Nutritionnelles et Cliniques. Centre d'Étude et d'Information sur les Vitamines, Produits Roche, Neuilly-sur-Seine, France.

Majee, D. N., E. C. Schwab, S. J. Bertics, W. M. Seymour, and R. D. Shaver. 2003. Lactation performance by dairy cows fed supplemental biotin and a B-vitamin blend. J. Dairy Sci. 86:2106-2112.

Manet, L. 1969. Techniques usuelles de biologie clinique. Page 39 in Hématologie. Éditions Médicales Flammarion, Paris, France.

McDowell, L. R. 2000. Vitamins in Animal and Human Nutrition. 2nd ed. Iowa State, University Press, Ames.
McMahon, R. J. 2002. Biotin in metabolism and molecular biology. Annu. Rev. Nutr. 22:221-239.

Midla, L. T., K. H. Hoblet, W. P. Weiss, and M. L. Moeschberger. 1998. Supplemental dietary biotin for prevention of lesions associated with aseptic subclinical laminitis (pododermatis aseptica diffusa) in primiparous cows. Am. J. Vet. Res. 59:733-738.

Milligan, L. P., J. M. Asplund, and A. R. Robblee. 1967. In vitro studies on the role of biotin in the metabolism of rumen microorganisms. Can. J. Anim. Sci. 47:57-64.

NRC. 2001. Nutrient Requirements of Dairy Cattle. 7th rev. ed. Natl. Acad. Sci., Washington, DC.

Preynat, A., H. Lapierre, C. M. Thivierge, M. F. Palin, J. J. Matte, A. Desrochers, and C. L. Girard. 2009. Effects of supplements of folic acid, vitamin $\mathrm{B}_{12}$, and rumen-protected methionine on whole body metabolism of methionine and glucose in lactating dairy cows. J. Dairy Sci. 92:677-689.

Rémond, D., I. Ortigues-Marty, A. Isserty, and J. Lefaivre. 1998 Technical note: Measuring portal blood flow in sheep using an ultrasonic transit time flow probe. J. Anim. Sci. 76:2712-2716.

Rémond, D. C. Poncet, and J. Lefaivre. 1993. Technical note: Ruminal vein catheterization and continuous blood flow measurement in ruminal arteries of sheep. J. Anim. Sci. 71:1276-1280.

Reynolds, C. K. 1995. Quantitative aspects of liver metabolism in ruminants. Pages 351-371 in Ruminant Physiology: Digestion, Metabolism and Reproduction. Proc. 8th International Symposium on Ruminant Physiology. W. v. Engelhardt, S. Leonhard-Marck, G. Breves, and D. Giesecke, ed. Ferdinand Enke Verlag, Stuttgart, Germany.

Reynolds, C. K. 2006. Production and metabolic effects of site of starch digestion in dairy cattle. Anim. Feed Sci. Technol. 130:78-84.

Reynolds, C. K., D. E. Beever, W. Steinberg, and A. J. Packington 2007. Net nutrient absorption and liver metabolism in lactating dairy cows fed supplemental dietary biotin. Animal 1:375-380.

Reynolds, P. J., G. B. Huntington, and C. K. Reynolds. 1986. Determination of volatile fatty acids, lactate and $\beta$-hydroxybutyrate in blood by ion exchange clean-up and gas chromatography. J. Anim. Sci. 63(Suppl. 1):424.

Rosendo, O., C. R. Staples, L. R. McDowell, R. McMahon, L. Badinga, F. G. Martin, J. F. Shearer, W. M. Seymour, and N. S. Wilkinson. 2004. Effects of biotin supplementation on peripartum performance and metabolites of Holstein cows. J. Dairy Sci. 87:2535-2545.

Santschi, D. E., R. Berthiaume, J. J. Matte, A. F. Mustafa, and C. L. Girard. 2005b. Fate of supplementary B-vitamins in the gastrointestinal tract of dairy cows. J. Dairy Sci. 88:2043-2054.

Santschi, D. E., J. Chiquette, R. Berthiaume, R. Martineau, J. J. Matte, A. F. Mustafa, and C. L. Girard. 2005a. Effects of the forage to concentrate ratio on B-vitamin concentrations in different ruminal fractions of dairy cows. Can. J. Anim. Sci. 85:389-399.

SAS Institute. 2004. SAS/STAT User's Guide. Volume 1-7. SAS Institute Inc., Cary, NC.

Scott, H. W., and B. A. Dehority. 1965. Vitamin requirements of several cellulolytic rumen bacteria. J. Bacteriol. 89:1169-1175.

Seal, C. J., and D. S. Parker. 1994. Effect of intraruminal propionic acid infusion on metabolism of mesenteric- and portal-drained viscera in growing steers fed a forage diet: I. Volatile fatty acids, glucose, and lactate. J. Anim. Sci. 72:1325-1334.

Seal, C. J., D. S. Parker, and P. J. Avery. 1992. The effect of forage and forage-concentrate diets on rumen fermentation and metabolism of nutrients by the mesenteric- and portal-drained viscera in growing steers. Br. J. Nutr. 67:355-370.

Zimmerly, C. A., and W. P. Weiss. 2001. Effects of supplemental biotin on performance of Holstein cows during early lactation. J. Dairy Sci. 65:267-277. 